\title{
APLIKASI KLINIK RENOGRAF IR-03 UNTUK RUMAHSAKIT: TEKNOLOGI DAN ANALISIS BIAYA
}

\author{
Rill Isaris, Suharni \\ Pusat Teknologi Akselerator dan Proses Bahan BATAN \\ Jl. Babarsari Kotak Pos 6101 ykbb, Yogyakarta 55281 \\ Joko Sumanto \\ Pusat Rekayasa Perangkat Nuklir BATAN \\ Kawasan PUSPIPTEK Serpong, Tangerang \\ Bagaswoto P, Eli Purwanti \\ RSUP Dr. Sardjito Yogyakarta \\ e-mail : ptapb@batan.go.id
}

Diterima 12 Desember 2010, diterima dalam bentuk perbaikan 04 Januari 2011, disetujui 02 Februari 2011

\section{ABSTRAK}

APLIKASI KLINIK RENOGRAF IR-03 UNTUK RUMAHSAKIT: TEKNOLOGI DAN ANALISIS BIAYA. Teknik Renografi menggunakan Alat Renograf adalah salah satu modalitas pemeriksaan fungsi ginjal selain dengan pemeriksaan laboratorium dan teknik Sinar-X. Renograf IR-03 untuk pemeriksaan fungsi ginjal hasil rancangbangun BATAN telah dikonstruksi dan menjalani uji laboratorium di PRPN-BATAN Serpong dan uji klinis di RSUP $D R$. Sardjito Jogyakarta. Biaya yang berkaitan dengan pemakaian klinik Alat Renograf di rumahsakit telah dianalisis yang terdiri dari komponen nilai radiofarmaka dan nilai investasi alat Renograf. Perhitungan biaya radiofarmaka hippuran ${ }^{131}$ lodine per tahun dengan estimasi jumlah pasien 2000 orang sebesar Rp. 30 juta, Total Direct Cost adalah Rp. 212,5 juta dan biaya modal satu Alat Renograf sebesar Rp. 250 juta. Nilai Titik Impas (Break Event Point) Investasi satu Alat Renograf adalah 1194 (0,597\%) atau setara Rp. 209,475 juta, dengan biaya per prosedur adalah Rp. 85.000,-. Harga ini tergantung pada beberapa variable terutama volume (kapasitas pelayanan pasien). Perhitungan analisis Cash-Flow untuk melihat seberapa jauh investasi tersebut menarik dan memberi prospek ke masa depan menunjukkan nilai Rate of Return yang diperoleh yaitu ROR (i) adalah 22,6\%, jauh diatas suku bunga simpanan Bank saat ini yaitu $<10 \%$. Perhitungan analisa Payback Period menunjukkan nilai 1,818 tahun, sangat prospektif secara ekonomi.

Kata kunci : Analisis biaya, renograf diagnostik, diseminasi produk

\section{ABSTRACT}

CLINICAL APPLICATION OF RENOGRAF IR-03 FOR THE HOSPITAL: TECHNOLOGY AND COST ANALYSIS The renography using Renograph is one of clinical modality to investigate the renal function among other such as laboratory medical check up and X-rays.. The prototype of Renograf IR-03 designed by BATAN has been constructed and laboratory tests as well as clinical tests have been carried out at PRPN-BATAN Serpong and General Hospital Dr. Sardjito Jogyakarta respectively. Cost associated with the clinical use of Renograph at the hospital are analyzed according to the two major components: radiopharmaceutical cost and the use of equipment. Annual cost of operational of Renograph by estimate number of patient is about 2000 are IDR.30.0 millions for radiopharmaceutical ${ }^{131}$ lodine. Total Direct Cost is about IDR.212.5 millions and the Capital Cost for one unit Renograph is IDR. 250 millions. The Break Event Point of invest one unit Renograph is 1194 procedures (0,597\%), or about IDR. 209.475 millions, which the cost for each procedure is IDR.85.000.-. This value is depending on several variables, especially number of procedure can be reached. The cash flow analysis by Rate of Return (ROR) showed that the value of $(i)$ is $22.6 \%$ is much greater than the value of MARR or saving rate of interest in the Bank now is about $<10 \%$. The Payback Period calculation to see on how interesting the investment of Renograph and its prospect for application in the hospitals showed about 1.818 years, that is good prospect economically.

Keywords : Cost analysis, diagnostic renograf, dissemination of product

\section{PENDAHULUAN}


umlah penderita kelainan fungsi ginjal menunjukkan peningkatan dalam dua dasa warsa terakhir ini, 20.000 pasien baru per tahun terdeteksi di rumahsakit pemerintah, serta terdapatnya peningkatan pasien melakukan terapi cuci darah. Pelayanan medik untuk memeriksa kelainan fungsi ginjal di rumahsakit terkendala oleh hampir tidak tersedianya peralatan Renograf, yang pengadaannya dengan import dan harga yang cukup mahal, dan tidak diproduksi lagi di negara maju. Sejak 1985 BATAN telah mengembangkan berbagai generasi prototip Renograf, inovasi teknologi dilakukan untuk tujuan penggunaan teknologi baru (state of the art), peningkatan kualitas dan unjuk kerja alat, kemudahan dan kenyamanan pemakaian di rumahsakit. Renograf IR-03 adalah alat untuk pemeriksaan fungsi ginjal berbasis teknologi radioisotop (nuklir) yang kompak, mampu mengidentifikasi secara spesifik fungsi kedua ginjal dan menghitung parameter fungsi ginjal dengan waktu singkat (15 menit).

Renografi, adalah modalitas pemeriksaan fungsi ginjal yang memiliki keunggulan daripada pemeriksaan konvensional seperti pemeriksaan laboratorium (creatinine, ureum dan asam urat ) atau teknik sinar- $X$, dan memiliki nilai diagnostik yang potensial (spesifik dan terukur), dan telah dikenal di rumah sakit. Kuantifikasi fungsi ginjal dengan radionuklida adalah merupakan metoda yang akurat dan tepat untuk evaluasi total (global) dan differensial (split, relative) fungsi ginjal berdasarkan konsep Smith yang dikemukakan oleh Eva V. Dubobsky, 1992. ${ }^{(1)}$ Monitoring secara eksternal di daerah pada kedua ginjal menghasilkan kurva aktivitas vs waktu (renogram) yang merupakan ekspresi perubahan aktivitas radioisotop (jumlah cacah) terhadap waktu. Tingkat uptake terhadap radiofarmaka menjadi dasar untuk perhitungan besaran Glomerular Filtration Rate (GFR) dan Effective Renal Plasma Flow (ERPF) pada masing-masing ginjal. BATAN telah berpartisipasi dalam mengembangkan rancangbangun alat Renograf sejak tahun 1985 dan menghasilkan sekitar 6 generasi alat. Menurut kajian Rill Isaris, 2007, ${ }^{(2)}$ evolusi dan peningkatan teknologi prototip Renograf yang menyangkut sophistikasi dan state of the art komponen, sistem antarmuka serta sistem komputer dan sistem instrumentasi kendali proses telah menunjukkan perkembangan dalam hal keandalan, unjuk kerja dan tampilan sistem sekitar 20 unit Renograf yang telah dihasilkan dan sebagian telah diuji coba di berbagai rumahsakit. Karena siklus teknologi yang sangat pendek dewasa ini, maka Renograf yang telah dipakai lebih 5 tahun tidak layak lagi secara teknologi dioperasikan dan terdapat kendala tidak tersedianya komponen ketika alat rusak, dan tidak kompatibel dengan teknologi komputer dewasa ini. Melalui beberapa kegiatan proyek riset, telah dihasilkan Renograf generasi baru yang memperhatikan state of the art komponen, ergonomi untuk pasien, kekompakan alat sehingga mudah untuk mobilitas ke daerah dan pemrosesan data dengan komputer dan perangkat lunak baru.

Dengan dukungan Program Insentif Kantor Kementrian Riset dan Teknologi, telah selesai dibuat Dokumen BEDP Prototip Renograf IR-03 dan kemudian dikonstruksi sebagai Demo-Plant untuk menjalani uji klinis dengan pasien di Rumah Sakit Umum Pusat Dr. Sardjito Jogyakarta. Pengujian ini dimaksudkan untuk menganalisis kelayakan teknologi desain, yang indikasinya ditunjukkan dengan tingkat keberhasilan pengoperasian, tingkat kegagalan/mal-function yang terjadi, kepuasan pemakai alat, keberhasilan menyelesaikan diagnosis pada pasien. Tujuan selanjutnya juga untuk mendapatkan data-data operasional alat untuk keperluan analisis manajemen, seperti analisis kelayakan ekonomi, analisis biaya untuk pertimbangan investasi alat Renograf.

Aplikasi klinis Renograf saat ini difokuskan untuk studi dan pemeriksaan fungsi ginjal pada pasien yang telah menderita kelainan fungsi ginjal untuk membuat diagnosis, dan untuk keperluan routine medical check up (preventif) pasien yang masih sehat. Secara makro kebutuhan rumah sakit akan alat Renograf masih tinggi, terdapat sekitar 20.000 pasien baru/1 juta penduduk/tahun di Indonesia.

\section{TINJAUAN TEKNOLOGI}

Organ ginjal dibentuk oleh suatu tubulous system yang berfungsi untuk mengatur dan memisahkan cairan hasil metabolisme dalam tubuh, dan membuang komponen yang tak berguna melalui urin. Setiap ginjal memiliki sekitar 1,2 juta neupron yang secara bersama -sama melakukan proses penyaringan, menyerap kembali, dan memisahkan. Menurut fungsinya neupron terbagi dua, yaitu glomeroleus yang berfungsi sebagai filter, dan tubulous untuk pemrosesan produk yang disaring dan diikuti proses penyerapan kembali dan memisahkan 
sisanya untuk dibuang sebagai urin. Menurut Rill Isaris, ${ }^{(2)}$ dari mekanisme produksi urin, fungsi ginjal adalah untuk keperluan sbb:

- Mengatur keseimbangan volume cairan tubuh dan komposisi di dalamnya, yang mengatur volume darah dan konsentrasi ion elemen $\mathrm{K}, \mathrm{Na}, \mathrm{Mg}, \mathrm{Ca}$. Kegagalan ginjal menjalankan fungsi ini menyebabkan ketidakseimbangan metabolisme dalam tubuh dan bias menyebabkan komplikasi ke organ yang lain.

- Mengatur keseimbangan asam-basa, yang terdiri dari pengaturan konsentrasi ion hidrogen dalam cairan selular ekstra tubuh. Kegagalan fungsi ini akan menyebabkan pasien koma jika terjadi kondisi ultra-acid atau odem jika cairan bersifat ultra-base.

- Mengatur tekanan darah dalam tubuh. Kegagalan fungsi ini menyebabkan rusaknya neupron yang ditunjukkan dengan perubahan koefisien filtrasi glomerolous.

Diagnosis terhadap ginjal didasarkan kepada analisis terhadap fungsi ginjal, yang dimanifestasikan dengan cara mendeteksi distribusi radiofarmaka dalam organ ginjal seseorang yang diinjeksi dengan radioisotop, misalnya I-131 hippuran (364 keV) atau Tc-99m DTPA (140 keV) melalui intravena. Jumlah radioaktivitas yang masuk dengan cepat ke dalam dan keluar dari ginjal menunjukkan distribusi yang spesifik terhadap fungsi waktu (seperti kurva hiperbola), yang disebut sebagai kurva renogram fungsi ginjal. Menurut Gogot Suyitno ${ }^{(3)}$ dan O'Reilly, et.al. ${ }^{(4)}$ kurva renogram terdiri dari 3 fase dan 5 patron seperti ditunjukkan dalam Gambar 1 . Fase I disebut fase vascular saat darah yang mengandung radioisotop memasuki ginjal yang menggambarkan kapasitas dan integritas ginjal, fase II disebut fase parenchyma, menggambarkan kapasitas absorbsi oleh ginjal, dan fase III disebut fase excretion, menggambarkan kemampuan ginjal mengeluarkan darah beserta radioisotop di dalamnya dan cairan lainnya. Ginjal yang berfungsi normal kurva fungsi ginjalnya ditunjukkan oleh patron $\mathrm{A}$.

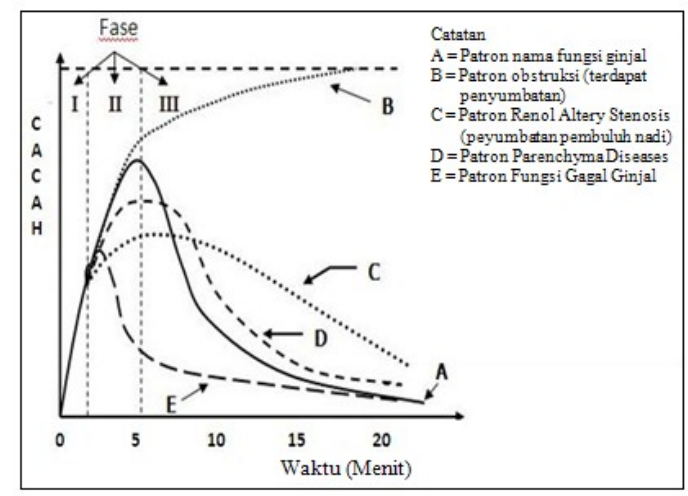

\section{Gambar 1. Fase dan Patron Kurva Renogram}

Mengingat bentuk kurva renogram dalam implementasi pada pasien relatif ada yang serupa, maka analisis kelainan fungsi ginjal secara lebih tepat untuk diagnosis dibantu dengan perhitungan dan definisi parameter ginjal seperti yang dikemukakan oleh Gogot Suyitno), ${ }^{(5)}$ definisi dan formulasinya ditunjukkan pada Tabel 1.

Tabel 1. Besaran dan Parameter Fungsi Ginjal

\begin{tabular}{|c|l|l|l|}
\hline No. & Notasi & \multicolumn{1}{|c|}{ Definisi } & \multicolumn{1}{|c|}{ Formulasi/Keterangan } \\
\hline 1. & $T_{\max }$ & Waktu untuk mencapai cacah maksimum $C_{\max }$ & Puncak kurva renogram \\
\hline 2. & $C_{\max }$ & Cacah maksimum & Jumlah cacah pada puncak kurva \\
\hline 3. & $T_{1 / 2}$ & $\begin{array}{l}\text { Interval waktu antara } T_{\max } \text { dan waktu ketika cacah } \\
=1 / 2 C_{\max }\end{array}$ & $\begin{array}{l}\text { Untuk perhitungan laju pengeluaran } \\
\text { cairan dari ginjal sampai } 1 / 2 \text { bagian }\end{array}$ \\
\hline 4. & $T_{2 / 3}$ & $\begin{array}{l}\text { Interval waktu antara } T_{\max } \text { dan waktu ketika cacah } \\
=2 / 3 C_{\max }\end{array}$ & $\begin{array}{l}\text { Untuk perhitungan laju pengeluaran } \\
\text { cairan dari ginjal sampai } 2 / 3 \text { bagian }\end{array}$ \\
\hline 5. & $C_{T 10}$ & Cacah pada waktu $t=10$ menit & Untuk perhitungan kemampuan ekskresi \\
\hline
\end{tabular}




\begin{tabular}{|c|c|c|c|}
\hline 6. & $\begin{array}{l}\text { Up- } \\
\text { Slope }\end{array}$ & $\begin{array}{l}\text { Gradien pada fase II, } \\
C_{T_{1}}=\text { cacah pada } t=T_{1} \text { (akhir fase I) }\end{array}$ & $U S=\frac{C_{\max }-C_{T 1}}{C_{\max }} x \frac{1}{T_{\max }-T_{1}}$ \\
\hline 7. & $\begin{array}{l}D S T_{1 / 2} \\
C T_{1 / 2} \\
\end{array}$ & $\begin{array}{l}\text { Gradien kurva antara titik } t=T_{\max } \text { dan titik pada } t \\
=T_{2 / 3} \\
\text { Cacah pada saat mencapai } 1 / 2 C_{\max }\end{array}$ & $D S T_{1 / 2}=\frac{C_{\max }-C T_{1 / 2}}{C_{\max }} \times \frac{1}{T_{1 / 2}}$ \\
\hline No. & Notasi & Definisi & Formulasi/Keterangan \\
\hline 8. & $\begin{array}{l}\mathrm{DS} T_{2 / 3} \\
\mathrm{CT}_{2 / 3} \\
\end{array}$ & $\begin{array}{l}\text { Gradien kurva antara titik } t=T_{\max } \text { dan titik pada } t \\
=T_{1 / 2} \\
\text { Cacah pada saat mencapai } 2 / 3 C_{\max }\end{array}$ & $D S T_{2 / 3}=\frac{C_{\max }-C_{T 2 / 3}}{C_{\max }} \times \frac{1}{T_{2 / 3}}$ \\
\hline 9. & $\begin{array}{l}\text { Reno } \\
\text { Index }\end{array}$ & $\begin{array}{l}\text { Perbandingan Kurva Integral pada fase II dengan } \\
t=80 \mathrm{~s} / \mathrm{d} 140 \text { sekon. }\end{array}$ & $R I=\frac{\int_{80}^{100} C_{L e f t}(t) d t}{\int_{80}^{140} C_{\text {Right }}(t) d t}$ \\
\hline 10. & $\mathrm{RUD}_{\text {Right }}$ & $\begin{array}{l}\text { Estimasi kapasitas ginjal untuk menangkap } \\
\text { tracer radioaktif diinjeksikan pada ginjal kanan }\end{array}$ & $R U D_{\text {ight }}=\frac{C_{\max ())}-C_{T 1}}{\left[C_{\max (R)}-C_{T 1(R)}\right]\left[C_{\max (e f)}-C_{T(L L)}\right]} \times 10 \%$ \\
\hline 11. & $\begin{array}{l}\text { Excretio } \\
n\end{array}$ & $\begin{array}{l}\text { Individual Excretion = Estimasi kapasitas masing- } \\
\text { masing ginjal (kiri dan kanan) }\end{array}$ & $\%$ Excretion $=\frac{C_{\max }-C_{T 10}}{C_{\max }}$ \\
\hline
\end{tabular}

Renograf IR-03 didesain dengan spesifikasi sebagai berikut (Joko Sumanto, 2008). ${ }^{(6)}$

- Detektor menggunakan Nal(TI) 2×2" Bicron dengan kolimator Pb

- Preamplifier PA-14 Bicron, charge sensitive, positive pulse.

- Sistem interface dengan teknologi USB, sehingga dapat menggunakan komputer generasi terbaru (Komputer Pentium IV) dan Perangkat lunak Windows XP

- Sistem statik (kolimator + detector) mobile, dengan posisi ke arah vertikal atau horizontal.

- Sumber daya 220V/600 Watt

- Posisi pasien tidur terlentang atau duduk di kursi

- Dapat menggunakan radioisotop I-131 hippuran atau Tc-99m DTPA, dengan waktu periksa 15 s/d 20 menit.

Renograf IR-03 yang sudah terpasang dan digunakan di Instalasi Radiologi RSUP Dr.Sardjito ditunjukkan pada Gambar 2. Pembuatan Renograf IR-03 ini didanai oleh Program Riset Insentif No.025/KP/ D.PSIPTN/Insentif/PPK/2009 dari Kantor Kementerian Riset dan Teknologi tahun 2009, dan menjadi barang inventaris KKRT/KNRT.

Analisis teknologi akan dibuat berdasarkan hasil pengujian (riset) karakteristik yang dilakukan dan kaitan terhadap spesifikasi yang ditetapkan sebelumnya, khususnya pada analisis kurva renogram, catatan teknis operasional alat selama uji coba, masalah yang timbul dan ratio kegagalan terhadap keberhasilan pemeriksaan.

Analisis fungsi ginjal yang dibuat dari penafsiran kurva renogram ginjal pasien lebih kepada kemampuan fungsi de-uritic yaitu kemampuan ginjal mengeluarkan cairan yang masuk, dan tidak sampai pada analisis kemampuan fungsi biokimianya. 


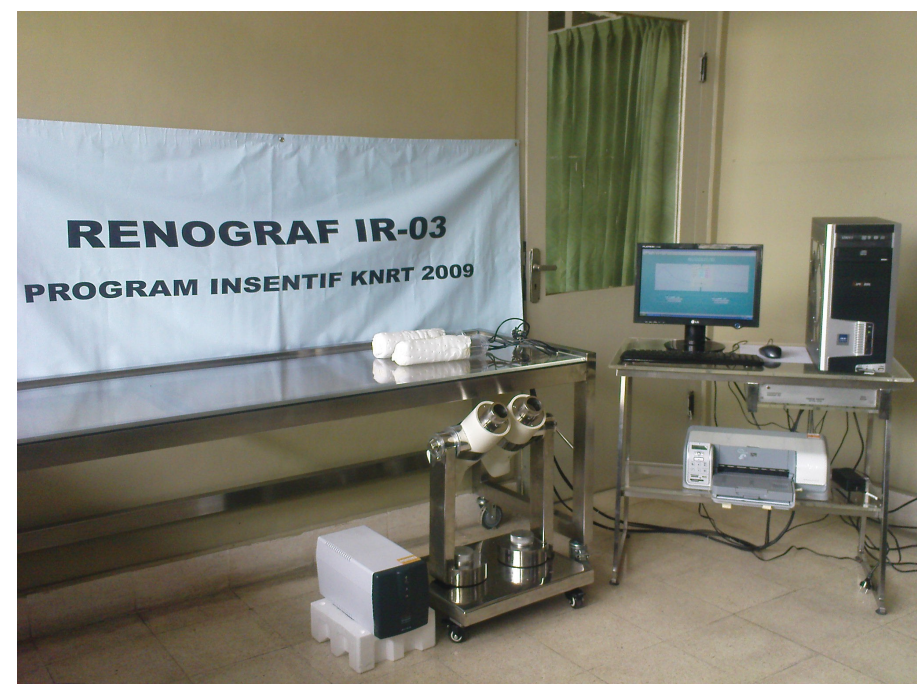

Gambar 2. Renograf IR-03 terinstalasi di RSUP Dr.Sardjito

sebagai berikut :

Dengan demikian klasifikasi fungsi ginjal dapat dikelompokkan ke dalam 3 kelompok dengan status

1. Penurunan fungsi : Ringan, Sedang, Berat, Minimal dan Non Fungsi

2. Obstruksi Parsial : Ringan, Sedang, Berat dan Total

3. Fungsi Normal

Analisis validasi hasil pemeriksaan renogram juga dibandingkan (inter-comparative) dengan hasil rekaman pemeriksaan laboratorium (normal creatinin (0,6 s/d 1,1 mg\%, dan normal ureum $10 \mathrm{~s} / \mathrm{d} 50 \mathrm{mg} \%$ ).

\section{Analisis Ekonomi Investasi Renograf}

Analisis biaya ekonomi dihitung berdasarkan komponen biaya diperlukan dalam operasional Renograf secara keseluruhan, yaitu Direct Cost (DC) dan Indirect Cost (IC) atau disebut juga Overhead Cost. DC terdiri dari komponen fixed cost (FC) berupa biaya pengadaan alat, biaya pemeliharaan, biaya personel dan variable cost (VC), berupa supplies. Menurut Evens, R.G.,1975 ${ }^{[7]}$ Indirect Cost/Overhead cost di industri pelayanan seperti kesehatan dapat mencapai 50\% Direct Cost. Overhead di dalam pelayanan kesehatan adalah biaya yang diperlukan untuk pelaksanaan pelayanan diagnostik, tetapi tidak bisa dihitung langsung dari fasilitas tsb. Termasuk hal ini adalah biaya administrasi (personel supervisor, ongkos ruang, pemeliharaan ruang, utilitas, sekuriti, parkir, pegawai kantor, dll.), layanan pendidikan, transkripsi, asuransi, billing-cost. Semua biaya ini diprediksikan untuk perhitungan dengan waktu per tahun. Total ongkos per tahun untuk melaksanakan $\mathrm{X}$ kali prosedur pemeriksaan fungsi ginjal merupakan penjumlahan $\mathrm{FC}$ dan $\mathrm{VC}$, atau :

$$
T C_{(x)}=F C+V C_{(x)}=F C+c X
$$

dengan $\mathrm{c}=$ biaya variabel untuk melaksanakan satu kali prosedur pemeriksaan .

Total Revenue (TR) diperoleh untuk $X$ kali prosedur dengan harga jual satu kali pemeriksaan $=p$ adalah $\mathrm{TR}_{(\mathrm{X})}=\mathrm{pX}$, dan ongkos $=\mathrm{cX}$.

\section{a) Break Event Point (BEP) atau Titik Impas}

Pada titik impas (Break Event Point), maka TR $=T C$, atau $\mathrm{pX}=\mathrm{FC}+\mathrm{CX}$., sehingga pada kondisi titik impas $\mathrm{pX}=\mathrm{FC}+\mathrm{CX}$. Dari persamaan ini diperoleh jumlah prosedur pelayanan diperlukan untuk mencapai titik impas adalah ${ }^{[8]}$ :

$$
B E P=X=\frac{F C}{p-c}
$$

\section{b) Rate of Return (ROR)}


Jika menghendaki kajian kelayakan investasi, dapat menggunakan metoda analisis alternatif investasi, seperti Net Present Value (NPV) atau Rate of Return (ROR). ROR akan menggambarkan tingkat suku bunga i ${ }^{*}$ yang berlaku pada serangkaian cash flow menjadi seimbang (pengeluaran = pendapatan), atau NPV $=0$. Selanjutnya nilai i* dibandingkan terhadap MARR (Minimum Attractive Rate of Return). Pada kondisi ROR, nilai NVP $=0$ (I Nyoman Pujawan, 1995, dan Ferianto Raharjo, 2007) ${ }^{[8,9]}$ :

$$
N P V=\sum_{t=0}^{N} F_{t}\left(1+i^{*}\right)^{-t}=0
$$

dengan $\mathrm{F}_{\mathrm{t}}=$ aliran kas pada periode $\mathrm{t}$ (bisa bernilai positif/revenue, dan negatif/expense)

$\mathrm{N}=$ umur proyek/peralatan

$i^{*}=$ nilai ROR diinginkan/discount-rate

Secara lengkap nilai $N P V=P V_{R}-P V_{E}$, atau persamaan (3) dapat ditulis:

$$
\sum_{t=0}^{N} R_{t}\left(P / F, i^{*} \%, t\right)-\sum_{t=0}^{N} E_{t}\left(P / F, i^{*} \%, t\right)=0
$$

dengan $\mathrm{R}_{\mathrm{t}}=$ Penerimaan neto pada periode ke $\mathrm{t}$

$E_{t}=$ Pengeluaran neto pada periode ke $t$, termasuk investasi awal $P_{0}$

$F / P=\left(1+i^{*}\right)^{N}$ atau Present Worth $P / F=\left(1+i^{*}\right)^{-N}$

Nilai $i^{*}$ dapat dicari dengan metoda Interpolasi Linear dan melihat pada Tabel Bunga, misalnya untuk Present Value $(P / F, i, 10)$, dengan $t=10$ tahun. Nilai tingkat bunga untuk investasi $i^{*}$ yang diperoleh selanjutnya dibandingkan terhadap nilai MARR, biasa diterjemahkan sebagai tingkat suku bunga simpanan di Bank pada waktu $=t$. Jika nilai $i^{*} \leq$ MARR, investasi pada proyek adalah tidak layak, dan jika i* $>$ MARR, maka investasi pada proyek tersebut adalah layak.

\section{c) Payback Period (PP), kecepatan pengembalian investasi modal}

Kecepatan pengembalian investasi modal $\left(t=N_{p}\right)$ dapat dihitung dengan persamaan:

$$
P=\sum_{t=1}^{t=N_{p}} N C F_{t}(P / F, i, t)
$$

atau jika time value of money diabaikan rumus (5) menjadi

$P=\sum_{t=1}^{t=N_{p}} N C F_{t}$, dan jika deretan arus kas besarnya sama, maka $N_{p}$ dapat dihitung, yaitu $N_{p}=\frac{P}{N C F}$, dengan $P=$ investasi awal, NCF $=$ Net Cash Flow (Pendapatan-Pengeluaran), atau secara lengkap dengan memperhatikan nilai depresiasi:

$$
N_{p}=\frac{P}{N C F+\text { Depresiasi }}
$$

\section{HASIL DAN PEMBAHASAN}

Sejak dioperasikan untuk pasien mulai 19 Oktober 2009 sampai 27 Januari 2010 ( 14 minggu, 5 hari pemeriksaan/minggu), tercatat jumlah pasien sebanyak 269 orang, dan diambil sebagai sampling data dari 180 pasien atau 360 buah ginjal yang memiliki data hasil pemeriksaan laboratorium (creatinin dan ureum) untuk dikomparasi dengan hasil pembacaan Renogram seperti ditunjukkan pada Tabel 2 dan 3.

Untuk keperluan penelitian di kedokteran, maka pasien dikategorikan ke dalam gender (laki-laki dan wanita) dan dalam 7 strata usia dari $<20$ tahun sampai $>70$ tahun.

Tabel 2. Observasi Hasil Uji Klinis Renograf IR-03 di RSUP Dr.Sardjito (Hasil Creatinine \& Ureum versus Kurva Urodinamik Fungsi Ginjal)

\begin{tabular}{|l|l|l|l|}
\hline & Creatinine $(\mathrm{mg} \%)$ & Ureum $(\mathrm{mg} \%)$ & Hasil Rekam Urodinamik Renogram \\
\hline
\end{tabular}


Aplikasi Klinik Renograf IR-03 Untuk Rumah Sakit; Teknologi dan Analisis Biaya

(Rill Isaris, Joko Sumanto, Suharni, Bagaswoto P., Eli Purwanti)

\begin{tabular}{|c|c|c|c|c|c|c|c|c|c|c|c|c|}
\hline \multirow[t]{2}{*}{$\begin{array}{c}\text { Gender } \\
\text { dan Usia }\end{array}$} & \multirow[t]{2}{*}{$<2$} & \multirow[t]{2}{*}{$2<x<10$} & \multirow[t]{2}{*}{$>10$} & \multirow[t]{2}{*}{$<30$} & \multirow[t]{2}{*}{$30<x<60$} & \multirow[t]{2}{*}{$>60$} & \multicolumn{2}{|c|}{$\begin{array}{c}\text { Menurun } \\
\text { Ringan }\end{array}$} & \multicolumn{2}{|c|}{$\begin{array}{c}\text { Menurun } \\
\text { Sedang }\end{array}$} & \multicolumn{2}{|c|}{$\begin{array}{c}\text { Menurun } \\
\text { Berat sd Non- } \\
\text { Fungsi } \\
\end{array}$} \\
\hline & & & & & & & $\mathrm{Ki} / \mathrm{Ka}$ & Bill & $\mathrm{Ki} / \mathrm{Ka}$ & Bill & $\mathrm{Ki} / \mathrm{Ka}$ & Bill \\
\hline \multicolumn{13}{|l|}{ Laki-laki } \\
\hline$<20$ thn & - & - & - & - & 3 & - & - & - & - & - & - & - \\
\hline $20-30$ & - & 2 & 2 & 1 & 1 & 2 & 2 & - & - & - & 2 & 4 \\
\hline $30-40$ & 1 & 5 & 1 & 2 & & 5 & - & 2 & - & 1 & - & 3 \\
\hline $40-50$ & 2 & 32 & 7 & 3 & 8 & 19 & 7 & 4 & 2 & 1 & 8 & 12 \\
\hline $50-60$ & - & 19 & 5 & 3 & 7 & 12 & 5 & 5 & - & 1 & 4 & 6 \\
\hline $60-70$ & 1 & 11 & 5 & 4 & 4 & 9 & 1 & 2 & - & 1 & 8 & 3 \\
\hline$>70$ & 1 & 3 & - & 1 & 1 & 2 & - & 1 & 1 & - & 2 & 1 \\
\hline Jumlah & 5 & 72 & 20 & 14 & 24 & 49 & 15 & 14 & 3 & 4 & 24 & 29 \\
\hline \multicolumn{13}{|l|}{ Wanita- } \\
\hline$<20$ thn & 1 & 2 & - & 1 & - & 2 & 1 & - & 1 & - & 2 & - \\
\hline $20-30$ & 1 & 3 & 2 & 1 & - & 5 & 1 & - & - & - & 4 & 2 \\
\hline $30-40$ & 1 & 7 & 7 & 2 & 4 & 9 & 1 & 2 & 2 & - & 1 & 9 \\
\hline \multirow{3}{*}{$\begin{array}{c}\text { Gender } \\
\text { dan Usia }\end{array}$} & \multicolumn{3}{|c|}{ Creatinine $(\mathrm{mg} \%)$} & \multicolumn{3}{|c|}{ Ureum (mg\%) } & \multicolumn{6}{|c|}{ Hasil Rekam Urodinamik Renogram } \\
\hline & \multirow[t]{2}{*}{$<2$} & \multirow[t]{2}{*}{$2<x<10$} & \multirow[t]{2}{*}{$>10$} & \multirow[t]{2}{*}{$<30$} & \multirow[t]{2}{*}{$30<x<60$} & \multirow[t]{2}{*}{$>60$} & \multicolumn{2}{|c|}{$\begin{array}{c}\text { Menurun } \\
\text { Ringan }\end{array}$} & \multicolumn{2}{|c|}{$\begin{array}{c}\text { Menurun } \\
\text { Sedang }\end{array}$} & \multicolumn{2}{|c|}{$\begin{array}{c}\text { Menurun } \\
\text { Berat sd Non- } \\
\text { Fungsi }\end{array}$} \\
\hline & & & & & & & $\mathrm{Ki} / \mathrm{Ka}$ & Bill & $\mathrm{Ki} / \mathrm{Ka}$ & Bill & $\mathrm{Ki} / \mathrm{Ka}$ & Bill \\
\hline $40-50$ & 1 & 17 & 5 & 5 & 8 & 11 & 4 & 1 & 3 & 1 & 5 & 14 \\
\hline $50-60$ & 1 & 10 & 2 & 4 & 3 & 6 & 5 & - & 1 & 1 & 0 & 4 \\
\hline $60-70$ & - & 3 & - & - & - & 3 & 1 & 2 & - & - & 0 & 2 \\
\hline$>70$ & 1 & 3 & 1 & 1 & - & 4 & - & 2 & - & - & 1 & 1 \\
\hline Jumlah & 6 & 45 & 17 & 14 & 15 & 40 & 13 & 7 & 7 & 2 & 13 & 32 \\
\hline $\begin{array}{c}\text { Jumlah } \\
\text { Total }\end{array}$ & 11 & 117 & 37 & 28 & 39 & 89 & 28 & 21 & 10 & 6 & 37 & 61 \\
\hline
\end{tabular}

Keterangan : Ki/Ka $=$ Kiri/Kanan, Bill = Bilateral

Tabel 3. Hasil Pemeriksaan Creatinine dan Ureum vs Urodinamik Fungsi Ginjal

\begin{tabular}{|c|c|c|c|c|c|c|c|c|c|c|c|}
\hline \multirow{3}{*}{ Gender } & \multicolumn{8}{|c|}{ Obstruksi } & \multirow{2}{*}{\multicolumn{3}{|c|}{ Normal }} \\
\hline & \multicolumn{2}{|c|}{ Ringan } & \multicolumn{2}{|c|}{ Sedang } & \multicolumn{2}{|c|}{ Berat } & \multicolumn{2}{|c|}{ Total } & & & \\
\hline & $\mathrm{Ki} / \mathrm{Ka}$ & Bill & $\mathrm{Ki} / \mathrm{Ka}$ & Bill & $\mathrm{Ki} / \mathrm{Ka}$ & Bill & $\mathrm{Ki} / \mathrm{Ka}$ & Bill & Kiri & Kanan & Bill \\
\hline \multicolumn{12}{|l|}{ Laki-laki } \\
\hline$<20$ thn & - & - & - & - & - & - & - & - & - & - & - \\
\hline $20-30$ & - & - & - & - & 1 & - & - & - & - & 1 & - \\
\hline $30-40$ & - & - & - & - & - & - & - & - & - & - & 1 \\
\hline $40-50$ & 3 & 1 & - & - & - & - & 1 & 5 & 2 & 1 & 0 \\
\hline $50-60$ & 2 & - & - & - & - & - & 6 & - & 1 & 1 & - \\
\hline $60-70$ & 1 & - & - & - & - & - & 2 & 1 & - & - & 2 \\
\hline$>70$ & - & 1 & - & - & - & - & 1 & - & - & - & 0 \\
\hline Jumlah & 6 & 2 & 0 & 0 & 1 & 0 & 10 & 6 & 3 & 3 & 3 \\
\hline \multicolumn{12}{|l|}{ Wanita } \\
\hline$<20$ thn & 1 & - & - & - & - & - & 1 & - & - & - & - \\
\hline $20-30$ & - & - & - & - & 1 & - & 2 & 1 & 1 & 2 & - \\
\hline
\end{tabular}




\begin{tabular}{|c|c|c|c|c|c|c|c|c|c|c|c|}
\hline $30-40$ & - & - & - & - & - & - & 1 & 2 & 2 & 1 & 2 \\
\hline $40-50$ & 2 & 1 & - & - & - & - & 2 & 1 & 2 & - & 1 \\
\hline $50-60$ & 3 & - & - & - & 1 & - & 1 & 1 & 0 & 0 & - \\
\hline $60-70$ & 1 & - & - & - & - & - & 0 & - & - & - & - \\
\hline$>70$ & - & - & - & - & - & - & - & - & - & 1 & - \\
\hline Jumlah & 7 & 1 & 0 & 0 & 2 & 0 & 7 & 5 & 5 & 4 & 3 \\
\hline $\begin{array}{c}\text { Jumlah } \\
\text { Total }\end{array}$ & 13 & 3 & 0 & 0 & 3 & 0 & 17 & 11 & 8 & 7 & $\mathbf{6}$ \\
\hline
\end{tabular}

Dari 178 orang pasien, hanya 165 pasien yang memiliki data hasil pemeriksaan laboratorium sebelumnya (creatinine dan ureum), sementara 13 pasien langsung diperiksa dengan renograf untuk memperoleh kurva renogramnya. Sehingga untuk mengetahui korelasi dan validasi hasil antara hasil pengukuran laboratorium terhadap hasil pengukuran renogram dibandingkan dari pasien yang memiliki hasil kedua moda pengukuran, yaitu sejumlah 165 pasien. Dari Tabel 2 dan 3 dapat dibaca informasi sebagai berikut:

1. Pasien laki-laki dengan hasil pengukuran creatinine antara $2 \mathrm{~s} / \mathrm{d} 10 \mathrm{mg} \%$ serta $>10 \mathrm{mg} \%$ dan hasil pengukuran ureum antara $2 \mathrm{~s} / \mathrm{d} 10 \mathrm{mg} \%$ serta $>10 \mathrm{mg} \%$ adalah terbanyak pada rentang usia antara $40 \mathrm{~s} / \mathrm{d}$ 70 tahun, yaitu 80 orang dari 98 pasien $(81,6 \%)$ dan 59 orang dari 98 pasien $(60,2 \%)$ berturut-turut.

2. Pasien wanita dengan hasil pengukuran creatinine $2 \mathrm{~s} / \mathrm{d} 10 \mathrm{mg} \%$ serta $>10 \mathrm{mg} \%$ dan hasil pengukuran ureum antara $30 \mathrm{~s} / \mathrm{d} 60 \mathrm{mg} \%$ serta $>60 \mathrm{mg} \%$ adalah terbanyak pada rentang usia 30 sampai 60 tahun, yaitu 50 orang dari 70 pasien $(71,4 \%)$ dan 41 orang dari 70 pasien $(58,6 \%)$ berturut-turut.

3. Kasus obstruksi ringan, sedang dan berat dari hasil kurva renogram tidak menunjukkan jumlah yang significant baik pada pasien laki-laki maupun wanita. Pada pasien laki-laki obstruksi total bilateral terdapat pada 6 pasien, obstruksi total pada salah satu ginjal saja ada 10 kasus, 2 ginjal kanan dan 8 ginjal kiri. Sementara pada pasien wanita, obstruksi total bilateral terdapat pada 5 pasien, obstruksi total pada salah satu ginjal saja ada 7 kasus, 4 ginjal kanan dan 3 ginjal kiri.

4. Hasil renogram yang menunjukkan fungsi ginjal masih normal pada pasien laki-laki adalah normal bilateral 3 pasien, normal ginjal kanan $=3$ dan normal ginjal kiri $=3$. Sementara untuk pasien wanita normal bilateral $=3$ pasien, normal ginjal kanan $=4$ dan normal ginjal kiri $=5$. Atau jumlah pasien laki-laki maupun wanita yang masih memiliki kedua ginjal masih baik $=6$ orang, dan yang memiliki salah satu ginjal masih baik $=15$ orang, atau jumlah ginjal analisis renogram yang masih normal adalah 24 buah.

Jika salah satu ginjal masih berfungsi baik dapat menghasilkan pengukuran creatinine dan ureum dalam batas normal.

Untuk melihat korelasi antara hasil pengujian laboratorium (pengukuran creatinine dan ureum) terhadap hasil kurva renogram serta validasinya, data pada Tabel 2 dan 3 disusun menjadi Tabel 4.

Tabel 4. Validasi Korelasi Hasil Uji Laboratorium versus Kurva Renogram

\begin{tabular}{|c|c|c|c|c|c|c|c|c|c|c|c|c|c|c|}
\hline \multirow{3}{*}{ Gender } & \multicolumn{6}{|c|}{$\begin{array}{l}\text { Hasil Pemeriksaan Laboratorium (darah) } \\
165 \text { sampel pasien (330 ginjal) }\end{array}$} & \multicolumn{8}{|c|}{ Hasil Pemeriksaan Kurva Renogram } \\
\hline & \multicolumn{3}{|c|}{ Creatinine (mg\%) } & \multicolumn{3}{|c|}{ Ureum (mg\%) } & \multicolumn{3}{|c|}{ Penurunan Fungsi } & \multicolumn{4}{|c|}{ Obstruksi } & \multirow[t]{2}{*}{ Normal } \\
\hline & $<2$ & $2 \sim 10$ & $>10$ & $<30$ & $30 \sim 60$ & $>60$ & Low & Med & High & Low & Med & High & Total & \\
\hline Pria & 5 & 72 & 20 & 14 & 24 & 49 & $30(5)^{*}$ & $8(5)$ & $56(30)$ & $8(2)$ & 0 & 1 & $16(6)$ & $6(3)$ \\
\hline Wanita & 6 & 45 & 17 & 14 & 15 & 40 & $20(7)$ & $9(2)$ & $51(32)$ & $8(1)$ & 0 & 2 & $16(6)$ & $9(3)$ \\
\hline Total & 11 & 117 & 37 & 28 & 38 & 89 & $50(12)$ & $17(7)$ & $107(62)$ & $16(3)$ & 0 & 4 & $32(12)$ & $15(6)$ \\
\hline Satuan & & & & rang & & & & & & 330 & & & & \\
\hline
\end{tabular}

Kerterangan : $\mathrm{XX}(\mathrm{Y})^{*}=$ jumlah kasus $\mathrm{XX}$ dengan $(\mathrm{Y})$ merupakan kasus billateral (pada kedua ginjal)

Dari Tabel 4 secara umum dapat diperoleh indikasi korelasi sebagai berikut: 
1. Sejumlah 11 pasien dengan nilai creatinine $<2 \mathrm{mg} \%$ yang termasuk ke dalam 28 pasien dengan kadar ureum $<30 \mathrm{mg} \%$, terindikasi pada analisis renogram sejumlah 12 pasien ginjalnya masih berfungsi normal, yang terdiri dari 9 orang dengan ginjal masih berfungsi pada salah satunya (kanan atau kiri saja) dan 3 pasien dengan kedua ginjal masih berfungsi normal.

2. Mayoritas pasien atau sejumlah 154 orang $(93,3 \%)$ dengan kadar creatine $>2 \mathrm{mg} \%$ dan kadar ureum $>30$ $\mathrm{mg} \%$, pada hasil analisis renogram terindikasi jumlah ginjal yang mengalami penurunan fungsi ringan sampai berat sebanyak 255 ginjal $(77,3 \%), 81$ kasus diantaranya penurunan fungsi pada kedua ginjal (bilateral), dan 67 ginjal (20\%) mengalami kerusakan fungsi/obstruksi, dengan 15 pasang mengalami kerusakan total. Atau total yang mengalami masalah dengan fungsi ginjal dengan analisis renogram sejumlah $77,3 \%+20 \%=$ $97,3 \%$.

Perhitungan kajian kelayakan ekonomi Renograf IR-03 untuk Aplikasi Klinis, yaitu tentang nilai BEP, ROR dan PP menggunakan data yang ditunjukkan pada Tabel 5.

Umur teknis didasarkan pada generasi komponen yang dipakai, jumlah pemakaian alat per tahun, kondisi pemeliharaan preventif ( power and environtment conditioning ), dan dalam hal ini mengacu pada Dokumen BEDP Renograf IR-03 PRPN-2008, yaitu maksimal 10 tahun. Umur pemakaian ekonomi secara normatif diambil sekitar $40 \%$ s/d $60 \%$ umur teknis, atau dapat ditentukan berdasarkan konsep Time Value of Money yang dihitung dengan persamaan:

$$
N P V=\sum_{i=1}^{N} \frac{F_{t}}{\left(1+i^{*}\right)^{N}}-F_{o}
$$

Pada saat proyek (alat) sudah tidak punya nilai ekonomi (pada saat umur ekonomi $\mathrm{N}=\mathrm{t}$ ), maka berlaku :

$$
\begin{aligned}
& N P V=\frac{F_{t}}{(1+0.226)^{t}}-F_{o}=0=\frac{R p .50 j u t a}{(1,226)^{t}}-R p .250 \text { juta } \\
& \quad \text { atau }(1,226)^{t}=\frac{R p .250 \text { juta }}{\text { Rp.50 juta }}=5 \text {, atau } \mathrm{t} \sim 8 \text { tahun, atau } 60 \% \text { nya adalah } 5 \text { tahun. }
\end{aligned}
$$

Jumlah pemeriksaan diperlukan untuk mencapai titik impas (BEP):

$$
B E P=X=\frac{\text { FixedCost }}{p-c}=\frac{107.500 .000}{175.000-85.000}=1194 \text { prosedur } / \text { pemeriksaan }
$$

\begin{tabular}{|c|c|c|c|}
\hline No. & Komponen Biaya & Nilai & Keterangan \\
\hline $\begin{array}{l}1 . \\
\text { a) }\end{array}$ & $\begin{array}{l}\text { Data dan Estimasi Ekonomi-Teknik } \\
\text { Umur Teknis Alat } \\
\text { Umur Pemakaian Ekonomi Alat } \\
\text { Pengadaan }{ }^{131} \mathrm{~h} \text { hippuran = } 1 \\
\quad \text { batch }=7 \mathrm{mCi} / \text { minggu } \\
\text { d) Pemakaian radioisotop = } 50 \\
\mu \text { Ci/prosedur } \\
\text { e) Estimasi pasien } / \text { minggu = } \\
40 \text { orang atau } 2000 \text { orang/thn. } \\
\text { f) Biaya Variabel } 1 \text { kali prosedur } \\
\text { pemeriksaan, atau } \\
c=\text { TC/jumlah prosedur = } \\
\text { Rp. } 161.600 .000 / 2000 \text { prosedur }\end{array}$ & $\begin{array}{lr} & 10 \text { tahun } \\
& \\
& 5 \text { tahun } \\
& \mathrm{Rp} . \\
& 1.250 .000 \\
\text { Rp. } & 8.928\end{array}$ & $\begin{array}{l}\text { Acuan BEDP Renograf PRPN-2008, } \\
\text { berdasarkan generasi komponen. } \\
\text { Nilai normatif 40-60\% umur teknis } \\
\text { Produk P.T.Batan Tekn. } \\
\text { Estimasi } \\
\text { Est. } 1 \text { tahun = } 50 \text { minggu } \\
\text { Biaya per prosedur }\end{array}$ \\
\hline
\end{tabular}

atau prosentase terhadap total target pemeriksaan/tahun $=[1194 / 2000] \%=59,7 \%$

Tabel 5. Biaya Tahunan Pemakaian 1 Unit Renograf IR-03 


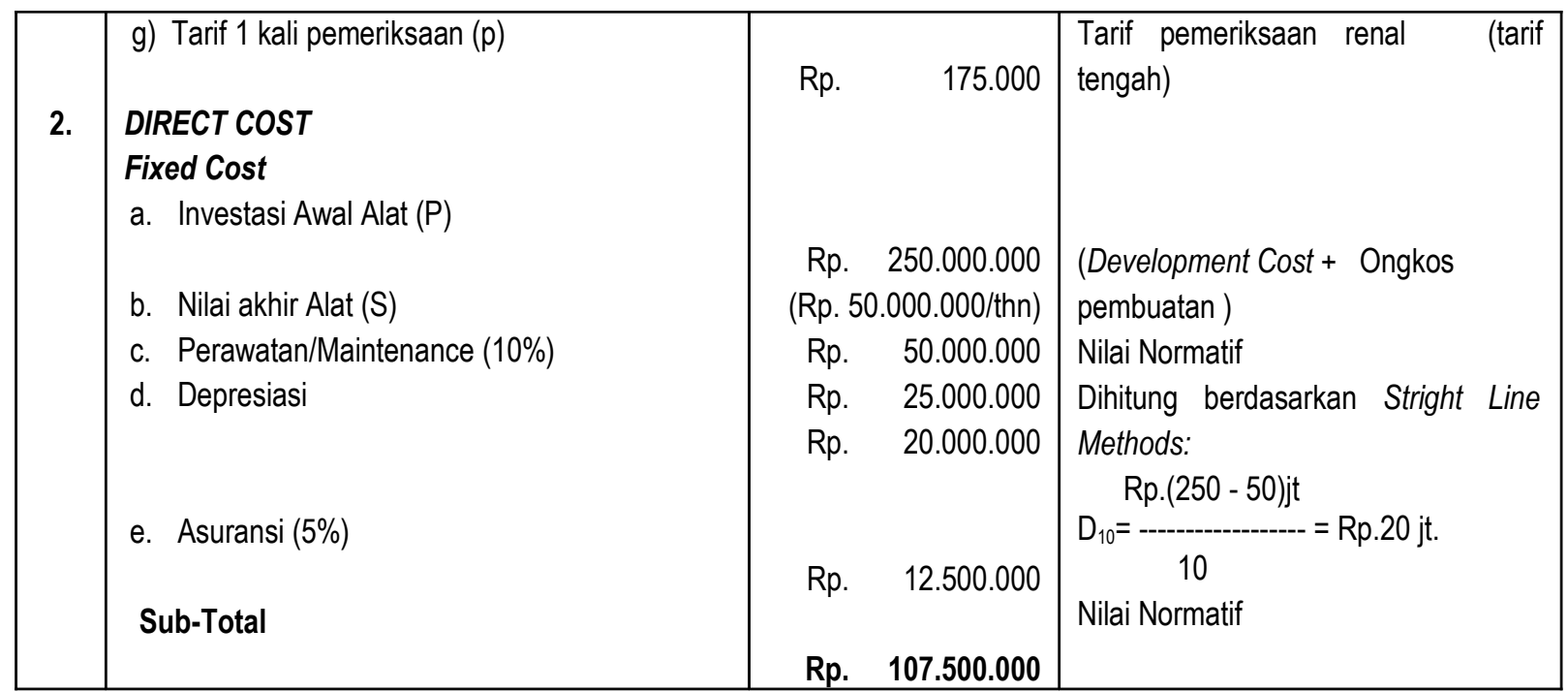

\begin{tabular}{|c|c|c|c|c|}
\hline \multirow[t]{2}{*}{ No. } & Komponen Biaya & \multicolumn{2}{|r|}{ Nilai } & Keterangan \\
\hline & $\begin{array}{l}\text { Variable Cost } \\
\text { a. Gaji Upah (1D, 1FM, 1E, 1AN) } \\
\text { b. Supplies /tahun } \\
\text { c. Radiofarmaka } 24 \text { batch/tahun } \\
\quad 24 x \text { Rp.1.250.000,- } \\
\text { Sub-Total }\end{array}$ & $\begin{array}{l}\text { Rp. } \\
\text { Rp. } \\
\text { Rp. } \\
\text { Rp. }\end{array}$ & $\begin{array}{r}60.000 .000 \\
15.000 .000 \\
30.000 .000 \\
105.000 .000\end{array}$ & $\begin{array}{l}\text { (Additional salaries) } \\
\text { Replaceparts, ATK } \\
\text { FOB rumahsakit }\end{array}$ \\
\hline & Sub Total/tahun & Rp. & 212.500 .000 & \\
\hline 3. & $\begin{array}{l}\text { INDIRECT COST } \\
\text { 1. Overhead Cost (20\% Direct Cost }\end{array}$ & Rp. & 34.000 .000 & Evens R.G. ${ }^{(7)}, 20 \mathrm{~s} / \mathrm{d}$ 50\%, \\
\hline & Total/tahun & Rp. & 246.500 .000 & \\
\hline
\end{tabular}

Jika dinyatakan dalam jumlah uang, nilai BEP $=1194 \times$ Rp.175.000 $=$ Rp. 209.475.000,- $\simeq$ 7,5 bulan Renograf beroperasi.

Biaya tahunan total operasional Renograf Rp. 212.500.000,-, jika Renograf dioperasikan selama 36 jam/minggu, 50 minggu/tahun, maka biaya operasional Renograf per jam adalah Rp. $212.500 .000 / 1.800$ jam $=$ Rp. 118.056,-ljam.

Untuk melihat kelayakan ekonomi lebih jauh digunakan analisis Cash Flow pada Rate of Return (ROR), yaitu menghitung seberapa tinggi bunga diperoleh pada investasi pada Alat Renograf, dan perolehan tingkat bunga tersebut dibandingkan terhadap Minimum Attractive Rete of Return (MARR), yaitu dianalogikan dengan tingkat suku bunga simpanan di Bank saat itu. Dalam kalkulasi ini, nilai ROR dihitung berdasarkan kondisi Net Cash Flow diestimasikan sama setiap waktu (tahun) dan mengabaikan time value of money, sehingga besarnya adalah:

NCF $=(2000 \times$ Rp. $1750.000-$ Rp. $212.500 .000,-)=$ Rp. 137.500.000,-. Umur ekonomi Renograf $(\mathrm{t})=5$ tahun. Jadi dihitung Present Value untuk $t=5$, yaitu $\mathrm{NPV}_{5}$, yang besarnya adalah :

$$
N P V_{5}=P V_{R}-P V_{E}=R(F, i \%, 5)-P=0
$$

Nilai Revenue selama 5 tahun adalah 5 x [ Rp. 350.000 .000 - Rp. 212.500.000 ] Atau $R_{5}=$ Rp.687.500.000 sehingga persamaan (7) diatas menjadi :

$$
\mathrm{NPV}_{5}=687.500 .000\left(\mathrm{P} / \mathrm{F}, \mathrm{i}^{*} \%, 7\right)-250.000 .000=0
$$

atau Faktor Present Value (P/F, i $\%, 5)=250.000 .000 / 687.500 .000=0,3634$ 
Dengan melihat Tabel Bunga Pemajemukan Diskrit, Present Value Factor yang nilainya berada di atas dan di bawah 0,3634 adalah pada bunga antara $20 \%$ dan $25 \%$., yaitu Faktor Present Value (P/F, 25\%,5) $=0,32768$ dan Faktor Present Value (P/F, 20\%,5) $=0,40188$. Keadaan ini dapat ditunjukkan pada Gambar 3, dan dengan Teknik Interpolasi Linear dapat ditentukan nilai i* sebagai berikut:

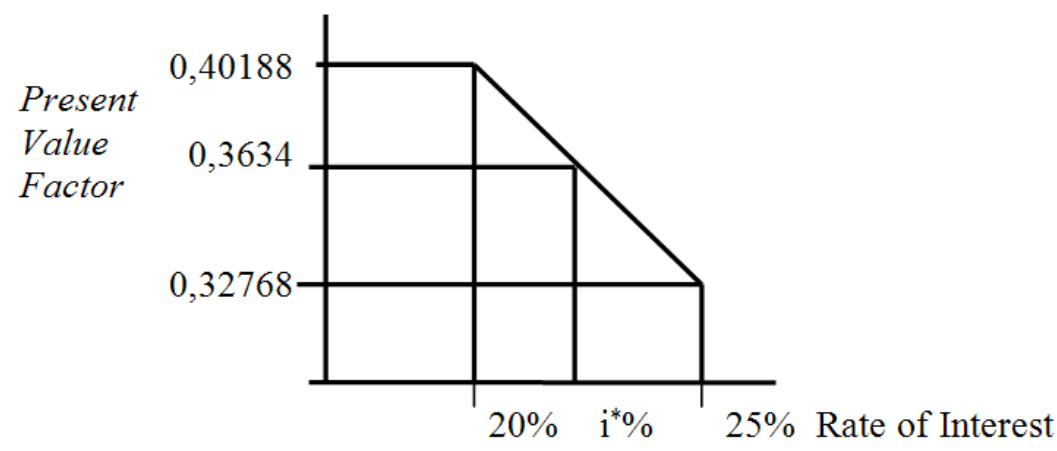

Gambar 3. Interpolasi Linear Perhitungan Bunga Majemuk

$$
\frac{25-i^{*}}{25-20}=\frac{0,36340-0,32768}{0,40188-0,32768}=0,4814
$$

Atau $25-i^{*}=5 \times 0,4814$, jadi $i^{*}=[25-2,4] \%=22,6 \%$, suatu tingkat bunga yang sangat prospektif, karena saat ini suku bunga simpanan di Bank (MARR) hanya $<10 \%$.

Kemudian analisis Payback Period menunjukkan hasil perhitungan PP sbb:

$P P=\frac{\text { Fixed Capital }}{N C F}=\frac{250.000 .000}{137.500 .000}=1,818$ tahun , sangat prospektif.

Untuk mendapatkan gambaran lebih jauh tentang investasi pada bisnis Renograf melalui analisis perkiraan harga jual pada berbagai tingkat keuntungan/laba yang diprediksikan, maka dilakukan perhitungan untuk laba $20 \%, 40 \%, 60 \%, 80 \%$ dan 100\% seperti ditunjukkan pada Tabel 6. Biaya dasar per prosedur pemeriksaan Renograf $=$ Rp. $85.000,-$

Dari Tabel 6 dapat disimpulkan bahwa keuntungan yang layak secara ekonomi minimal adalah antara $50 \%$ s/d 60\%, karena nilai Payback Period < 5 tahun. Tetapi jika efisiensi pemakaian Alat untuk pemeriksaan bisa tinggi, dan biaya tetap dan biaya variabel bisa ditekan, maka nilai PP juga bisa bergeser lebih kecil (lebih cepat pengembalian modal). Menetapkan keuntungan yang terlalu tinggi tidak bisa menjadi pilihan jika ada pesaing atau moda pemeriksaan lain, yang mungkin tarifnya lebih murah. Untuk pemeriksaan fungsi ginjal yang komprehensif dan efektif (pada kedua ginjal secara sendiri-sendiri), nampaknya moda renografi masih merupakan yang lebih baik dibanding pemeriksaan laboratorium atau dengan Pesawat X-Ray.

Tabel 6. Perhitungan BEP dan PP pada berbagai tingkat Keuntungan

\begin{tabular}{|c|c|c|c|c|}
\hline No. & $\begin{array}{c}\text { Tingkat Laba } \\
(\%)\end{array}$ & Harga Jual (Rp) & $\begin{array}{c}\text { Nilai BEP } \\
(\text { Prosedur / \% ) }\end{array}$ & $\begin{array}{c}\text { Nilai PP } \\
(\text { tahun) }\end{array}$ \\
\hline 1. & 40 & 119.000 & $3162 / 158$ & 9,80 \\
\hline 2. & 50 & 127.500 & $2559 / 128$ & 5,88 \\
\hline 3. & 60 & 136.000 & $2108 / 105$ & 4,20 \\
\hline 4. & 70 & 144.500 & $1807 / 90$ & 3,27 \\
\hline 5. & 80 & 153.000 & $1581 / 79$ & 2,67 \\
\hline
\end{tabular}




\begin{tabular}{|c|c|c|c|c|}
\hline 6. & 100 & 170.000 & $1265 / 63$ & 1,96 \\
\hline
\end{tabular}

Beberapa saran untuk tercapainya produktivitas dan efisiensi yang lebih tinggi pemakaian Renograf untuk pemeriksaan ginjal di rumahsakit adalah sbb:

1. Melakukan manajemen pengoperasian Renograf yang efisien, sehingga seluruh bahan radioisotop/radiofarmaka (1 batch $=7,5 \mathrm{~s} / \mathrm{d} 10 \mathrm{mCi}$ ) dapat dipakai secara efektif. Untuk itu perlu melakukan manajemen penyiapan jumlah pasien yang ketat. Menunggu tersedianya jumlah pasien yang terlalu lama menyebabkan kapasitas radioisotop akan berkurang, karena mengalami peluruhan ( $T_{1 / 2} \sim 6$ jam). Ketersediaan radiofarmaka ${ }^{131}$ lodine merupakan faktor yang penting untuk tercapainya kontinuitas pelayanan. Selama ini produksi dan distribusi radiofarmaka ini adalah produsen dalam negeri (PT. Batan Teknologi), yang pernah mengalami terhentinya produksi beberapa saat karena gangguan teknis di Instalasi Produksi Radioisotop Serpong. Hal ini bisa diatasi dengan membeli radiofarmaka tersebut dari pelayanan import, misalnya dari Malaysia dan Australia, hal ini masih memungkinkan karena $T_{1 / 2}$ nya sekitar 8 hari tetapi harganya akan lebih mahal. Oleh karena itu Manajemen pelayanan Radioisotop di Rumahsakit harus memiliki prosedur ketika produksi radioisotop didalam negeri mengalami masalah.

2. Melakukan promosi melalui Forum Profesi Kedokteran, sehingga jumlah kiriman pasien dari dokter umum dapat ditingkatkan.

3. Alokasi dana Pemeliharaan agar dimanfaatkan sebaik-baiknya terutama untuk pemeliharaan preventif alat serta perlindungan alat terhadap sumber daya elektrik dan temperatur ruangan, agar alat digunakan dalam ruang yang memiliki Power and Air Conditioning System, sehingga keberlanjutan operasional bisa terjaga.

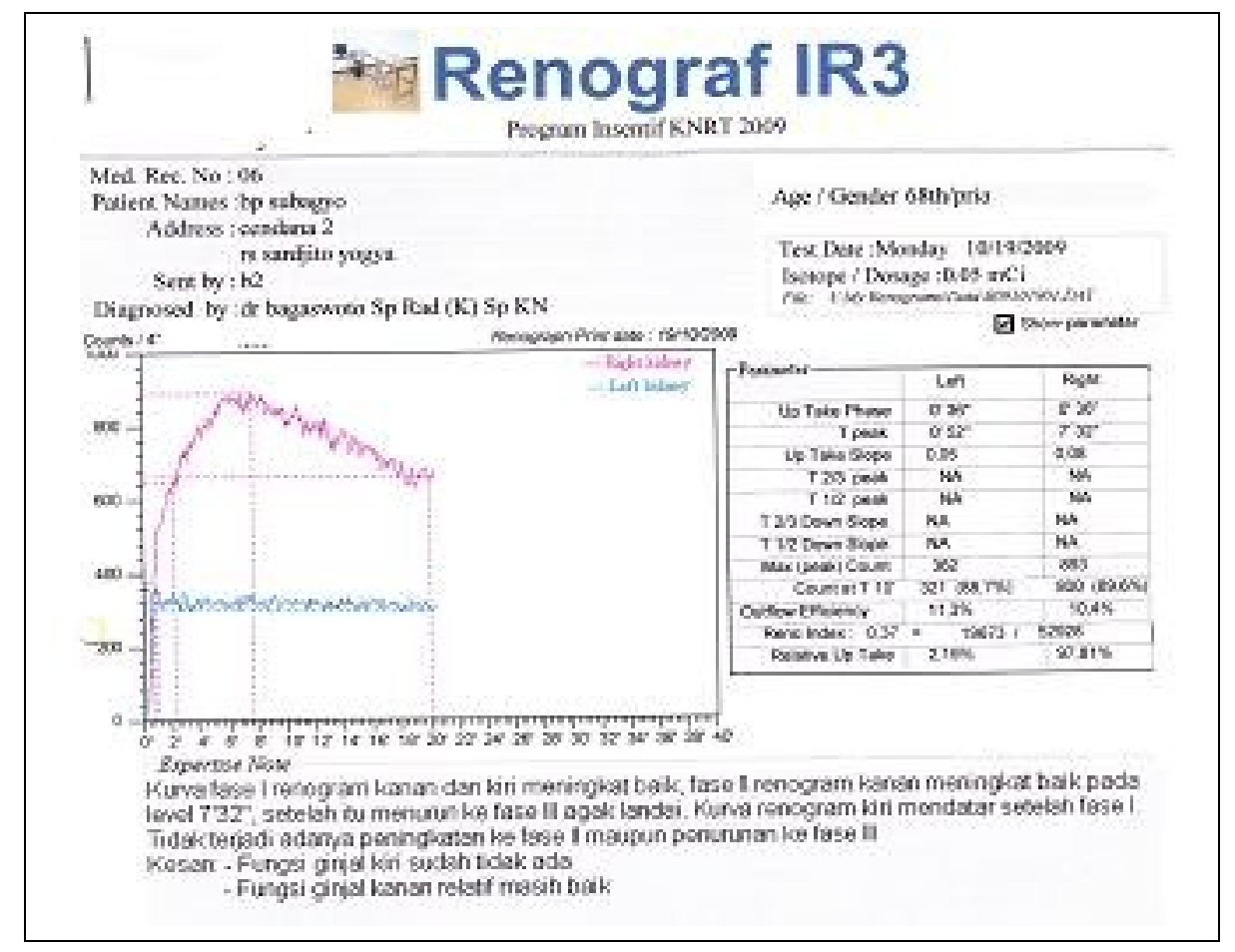

Gambar 4. Contoh Hasil Pemeriksaan Ginjal kasus salah satu Ginjal baik 


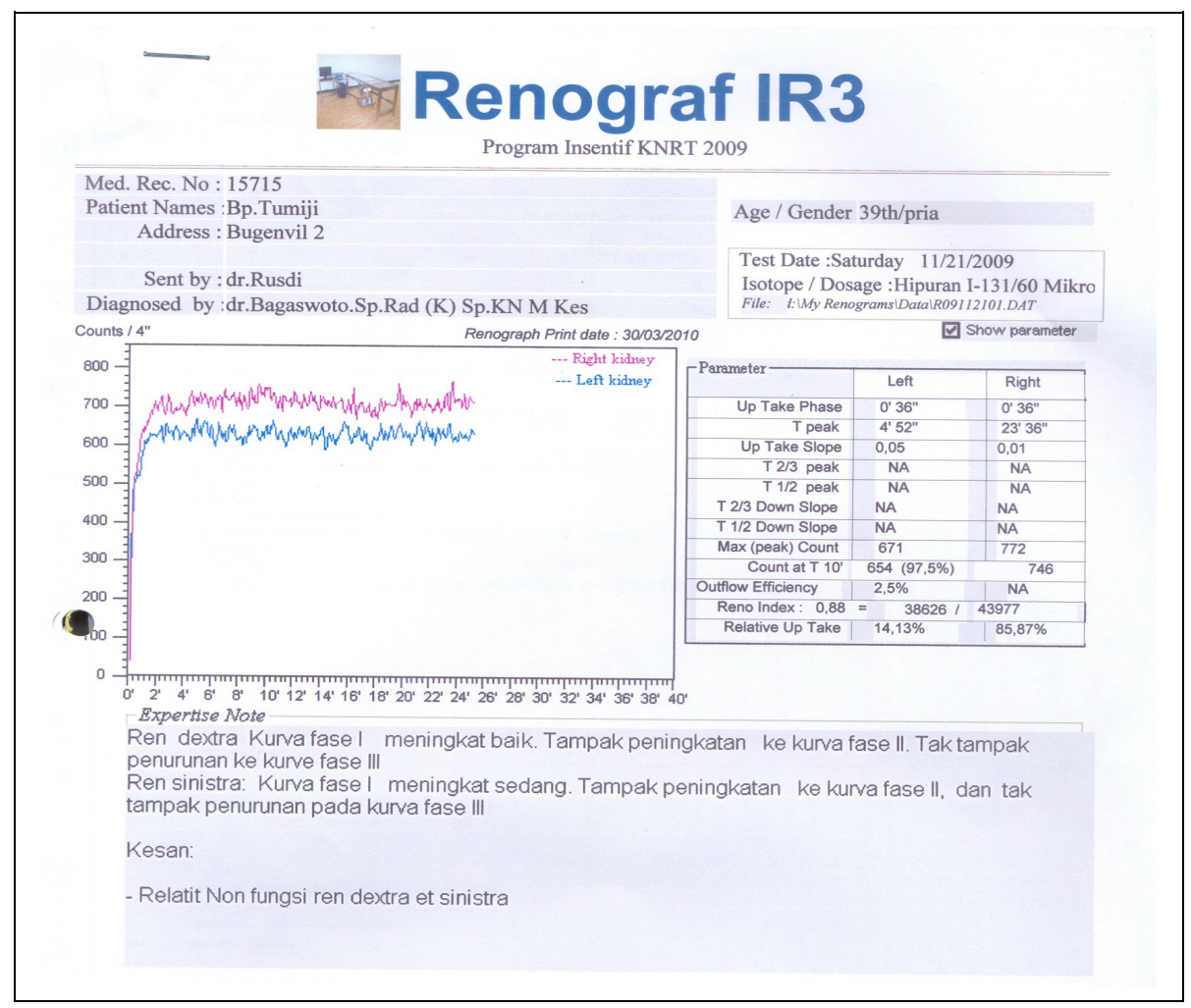

Gambar 5. Contoh Hasil Pemeriksaan Ginjal kasus Obstruksi pada kedua ginjal

Hasil kurva renogram dan parameter fungsi ginjal seluruh pasien direkam dan diolah serta disimpan oleh Personal Computer, data parameter dan kurva renogram dapat ditampilkan di layar monitor dan atau dicetak pada printer berwarna, sehingga dapat membedakan dengan mudah masing-masing ginjal. Gambar 4 menunjukkan contoh hasil rekaman kurva urodinamik fungsi ginjal pasien Subagyo 68 tahun (creatinine $=2,18$ dan ureum $=25$ ) dengan pemeriksaan renogram menunjukkan ginjal kanan masih baik dan ginjal kiri tidak berfungsi.

Gambar 5 contoh rekaman fungsi ginjal Bp. Tumiji yang menunjukkan telah terjadi obstruksi (penyumbatan) pada kedua ginjal. Fase vascular masih baik, tetapi up-take dan ekskresi sudah tidak menunjukkan fungsinya lagi.

\section{KESIMPULAN}

Pembuatan Demo Plant Renograf IR-03 diselesaikan tepat waktu sesuai dengan Dokumen BEDP yang telah ada, dan pengujian klinis alat dengan pasien sesungguhnya selesai dilaksanakan selama 3 bulan terus menerus di RSUP Dr. Sardjito Jogyakarta dengan lancar dan hasil baik. Dapat dikemukakan kesimpulan sebagai berikut :

1. Aplikasi Renograf IR-03 untuk Uji Fungsi Ginjal telah berjalan baik sesuai dengan Spesifikasi Teknis yang ditetapkan. Selama 14 minggu uji klinis, 269 orang pasien rumahsakit telah diperiksa (6 - 8 pasien/hari) tanpa alat mengalami kegagalan.

2. Analisis Tekno Ekonomi untuk melihat kelayakan jika berinvestasi pada bisnis Alat Renograf, telah dibuat dengan mengidentifikasikan dengan analisis Break Event Point, Payback Period, dan Rate of Return. Hasil analisis menunjukkan nilai BEP $=59,7 \%$ atau Rp. 209.475.000, Tingkat Bunga Investasi ROR $\left(i^{*}\right)=22,6 \%$ dan Payback Period $=1,818$ tahun. 
3. Biaya pemeriksaan untuk estimasi keuntungan mulai $50 \%$ sampai $70 \%$ yang merupakan prospektif bagus, memberikan tarif sebesar Rp. $127.500 \mathrm{~s} / \mathrm{d}$ Rp. 144.500, masih kompetitif dibandingkan tarif pemeriksaan yang sama dengan moda yang lain.

4. Analisis ekonomi menunjukkan, investasi Alat Renograf untuk Pemeriksaan Fungsi Ginjal Komersial menunjukkan prospek yang sangat bagus, pengembalian modal cepat $(<2$ tahun), pencapaian titik impas cukup bagus $(59,7 \%)$ dan nilai ekonomi investasi ditinjau dari sudut suku bunga investasi jauh lebih tinggi daripada suku bunga simpanan yang ditawarkan oleh Bank $(22,6 \%>10 \%)$.

5. Analisis Biaya (Cost Analysis) Renograf adalah alat yang penting untuk keperluan Pimpinan bisnis, administrator pelayanan medik dan Pembuat kebijakan di Bidang Kesehatan. Analisis Biaya ini hanya akan akurat sepanjang memenuhi asumsi/estimasi yang ditetapkan, tidak ada model yang dapat menjelaskan realitas dengan setepat-tepatnya, tetapi estimasi yang digunakan sudah memperhatikan faktor-faktor penting dalam pemakaian Renograf.

6. Kelancaran dan kontinuitas pelayanan pemeriksaan ginjal menghendaki ketersediaan radiofarmaka ${ }^{131}$ /odine yang berkesinambungan, oleh karena itu Manajemen Rumahsakit tidak hanya mengandalkan pengadaan radiofarmaka dari produk domestik, tetapi juga mempunyai kemampuan untuk membelinya dari produk import.

\section{SARAN}

Agar supaya hasil Litbangyasa Renograf IR-03 BATAN ini dapat teraplikasi secara normatif di rumah sakit dan poliklinik, maka satu langkah terakhir yang perlu dilakukan adalah mengupayakan terbitnya Sertifikasi Produk dari KemenKes dan izin pengoperasiannya dari Bapeten. PRPN dan PKTN serta BKHH dapat melakukan hal ini.

\section{UCAPAN TERIMA KASIH}

Pelaksanaan program Litbangyasa ini mendapat pembiayaan dari Kantor Kementerian Riset dan Teknologi, dengan kontrak Nomer: 025/KP/D.PSIPTN/Insentif/PPK/2009 dan bantuan pelaksanaan dari Peneliti dan Teknisi di PRPN-BATAN dan PTAPB-BATAN. Untuk itu Penulis mengucapkan penghargaan dan terima kasih atas pemberian dana pemnelitian dan partisipasi para pelaksana.

\section{DAFTAR PUSTAKA}

1. EVA V.DUBOVSKY, "Quantitation of Renal Function", Proceeding the $5^{\text {th }}$ Asia and Oceania Congress of Nuclear Medicine and Biology, Volume I, Jakarta-Bali, October (1992) 331-345.

2. RILL ISARIS, SETYADI W.S, "Evolution Design and Construction of Renograph for Renal Function Test", Proceedings of the 4-th Kentingan Physics Forum, A Biannual Conference on Physics and Its Application, UNS Surakarta, ISBN: 979-498-347-0.. (2007) 293-304

3. GOGOT SUYITNO, et.al, "131/ Hippuran Renography in Clinical Application for Renal Function Test, A Comparative Study to Renal Ultra Sonography", Proceeding Annual Congress on Nuclear Medicine and Biology Society, Yogyakarta (1989) 197

4. O'REILLY et.al, Nuclear Medicine in Urology and Nephrology, second edition Book, Butherworths, published in London and Boston (1979)

5. GOGOT SUYITNO, Medical Validation on Presented Data of Refurbishing Aged Renogram System, Technical Report of RAS/04/017 IAEA Programme, The IAEA Regional Training Workshop, Yangon, Myanmar (2001)

6. JOKO SUMANTO, Analisis Potensi Bahaya, Dampak \& Penanggulangannya Terhadap Penggunaan Perangkat Renograf Hasil Litbangyasa BATAN, Majalah IImiah PRIMA, PRPN-BATAN, ISSN : 1411-0296, Volume 5, Nomer 10, November (2008) 
Aplikasi Klinik Renograf IR-03 Untuk Rumah Sakit; Teknologi dan Analisis Biaya

(Rill Isaris, Joko Sumanto, Suharni, Bagaswoto P., Eli Purwanti)

7. EVENS, R.G., Cost Accounting in Radiology and Nuclear Medicine, CRC Crit. Rev. Clinical Radiology Nuclear Medicine, Vol.6 (1975) 67-69

8. I NYOMAN PUJAWAN, Ekonomi Teknik, Pemilihan Alternatif-Alternatif Ekonomi, Bab IV, V dan VI, Buku terbitan PT.Guna Widya (1995)

9. FERIANTO RAHARJO, Ekonom Teknik, Analisis Pengambilan Keputusan, Analisis NPV, PP, dan ROR, Bab 5, 8 dan 9, Buku Penerbit ANDI Yogyakarta (2007) 